\title{
Galápagos macroalgae: A review of the state of ecological knowledge
}

\author{
Paul Tompkins \& Matthias Wolff \\ Leibniz-Zentrum für Marine Tropenökologie, Fahrenheitstr. 6, D-28359 Bremen, Germany; \\ ptompkins25@gmail.com,matthias.wolff@zmt-bremen.de
}

Received 17-II-2015. Corrected 24-VIII-2016. Accepted 29-IX-2016.

\begin{abstract}
Previous work has highlighted the critical role of macroalgal productivity and dynamics in supporting and structuring marine food webs. Spatio-temporal variability in macroalgae can alter coastal ecosystems, a relationship particularly visible along upwelling-influenced coastlines. As a result of its equatorial location and nutrient rich, upwelling-influenced waters, the Galápagos Archipelago in the East Pacific, hosts a productive and biodiverse marine ecosystem. Reports and collections of macroalgae date back to the Beagle voyage, and since then, more than three hundred species have been reported. However, their ecology and functional role in the ecosystem is not well understood. According to various disparate and in part anecdotal sources of information, abundant and diverse communities exist in the Western regions of the archipelago, the North is essentially barren, and in the central/South abundance and distribution is variable and less well defined. Both oceanographic conditions and herbivore influence have been theorized to cause this pattern. Extensive changes in macroalgal productivity and community composition have occurred during strong ENSO events, and subsequent declines in marine iguana (an endemic and iconic grazer) populations have been linked to these changes. Iguanas are only one species of a diverse and abundant group of marine grazers in the system, highlighting the potentially important role of macroalgal productivity in the marine food web. This review represents a first compilation and discussion of the available literature and presents topics for future research. Rev. Biol. Trop. 65 (1): 375-392. Epub 2017 March 01.
\end{abstract}

Key words: Galápagos, macroalgae, ENSO, primary productivity, biogeography.

Marine macroalgae, or seaweeds as they are commonly known, are an important source of marine primary productivity, and provide a range of ecosystem services (Mann, 1973; Dayton, 1985). Macroalgal morphologies range from tiny simple filaments and crustose forms which creep along the seafloor and grow less than a millimeter a year to massive, towering species like the kelp Macrocystis which can grow half a meter a day and attain frond lengths of over 30 meters (Lobban \& Harrison, 1997). The species richness of kelp-associated benthic communities (specifically forests of Macrocystis) rivals that of the most biodiverse habitats on the planet (Dayton, 1985). Degradation or loss of macroalgal habitat results in fundamental changes in benthic community structure, and declines in functional diversity and overall productivity (Bodkin, 1988; Graham, 2004; Lilley \& Schiel, 2006). Macroalgal distributions are spatio-temporally variable due to a variety of factors including oceanography, disturbance, and herbivory (e.g. Kerswell, 2006; Santelices, Bolton, \& Meneses, 2009). Upwelling regions, and in particular island archipelagos within those regions, exhibit variable macroalgal distribution patterns across ranges of upwelling influences, making them ideal locations for the study of macroalgal biogeography and dynamics (Bustamante \& Branch, 1996; de Guimaraens \& Coutinho, 1996; Schils \& Coppejans, 2003b).

While macroalgal ecology in other upwelling influenced island systems (e.g. Canary 
Islands, Arabian Sea, California Current) has been well studied, the Galápagos archipelago is a notable exception. Because of its relative remoteness, oceanographic complexity, biological diversity, and high proportion of endemism, the Galápagos archipelago presents a 'living laboratory' for ecological and evolutionary investigations. Taxonomy and biogeography are particularly fruitful fields of investigation, and geographic affinities of marine mammals, birds, fish, and macroinvertebrate species have already been described (Harris, 1969; Grehan, 2001; Palacios, 2003; Edgar, Banks, Fariña, Calvopiña, \& Martinez, 2004). Oceanographic and meteorological processes combine in the equatorial East Pacific to create large spatiotemporal gradients in surface water temperatures across the Galápagos Islands (Palacios, 2004), and upwelled nutrient-rich waters create rich phytoplankton blooms twice as dense as in surrounding waters, supporting a highly productive marine ecosystem (Palacios, 2004; Pennington et al., 2006; Ruiz \& Wolff, 2011).

Macroalgae exist in the archipelago, and the most exhaustive (and available) investigations of Galápagos macroalgae have been taxonomic in nature (reviewed by Garske, 2002). Current estimates of marine macroalgal richness are upwards of 315 species, containing taxa representative of tropical and temperate waters. Ecological information includes anecdotal or coincidental observations of ecological patterns and processes, ecological models of shallow subtidal systems, and manipulative experiments designed to test top-down and bottom-up influences on the marine flora of the archipelago. This review offers a compilation and discussion of relevant literature-an attempt to summarize and integrate available knowledge-so that gaps in understanding of Galápagos macroalgal ecology may be identified as areas for future research. Three main themes include: 1) distributions (influences of oceanography, depth, and herbivores), 2) temporal dynamics (primarily the influence of El Niño Southern Oscillation-ENSO), and 3) functional role (grazer diversity and abundances, ecosystem services).
Material for this review was gathered from several sources, including the physical holdings of the Charles Darwin Foundation (CDF) Library, online information in the CDF's Datazone, and notations and samples from the collections at the CDF and University of California Berkeley Herbariums. Online searches for relevant literature, combined with institutional requests for specific materials, formed the balance of the review effort. Material reviewed dates from the earliest records available (1800's), to present day.

\section{DISTRIBUTIONS}

Regional variation: Via deleterious effects on physiology and competitive interactions, thermal stresses and nutrient limitations can limit macroalgal distributions (Adey \& Steneck, 2001). Global trends exhibit a propensity for diverse and abundant macroalgal communities to flourish in relatively cold, nutrient rich waters (higher latitudes), while entirely different and relatively species-poor assemblages of species inhabit warm and generally nutrientlimited tropical waters (Schils \& Coppejans, 2003a; Kerswell, 2006). This general pattern is confounded by smaller-scale physical and biological factors, such as tropical upwelling, anthropogenic nutrient pulses, and localized overabundances of grazers (Bell, 1992; Lobban \& Harrison, 1997). Work in other upwelling influenced areas has revealed oceanographic and herbivore related biogeographic patterns in macroalgal community compositions and biomasses, with diversity and abundances related positively to upwelling (colder, nutrient rich waters) influence, and negatively to grazer (urchin) abundances (Bustamante \& Branch, 1996; Schils \& Coppejans, 2003a; Sangil, Sansón, \& Afonso-Carrillo, 2011).

In Galápagos, consistent upwelling of cold waters at the archipelago's Western margin and seasonally alternating warm (surface waters from the Northeast) and cold (upwelled waters from the Southeast) currents cause the waters surrounding the islands to experience a range of temperatures and productivities over time. 
At the peak of upwelling, sea surface temperatures across the archipelago can differ by more than $10{ }^{\circ} \mathrm{C}$.

Previous work has identified distinct regions within the archipelago, based on both physical characteristics and organismal distributions (e.g. Harris, 1969). Edgar et al. (2004), for example, divided the archipelago into five main regions, based on biogeographic patterns of marine fish and macroinvertebrates. Patterns and trends in the distribution of Galápagos macroalgae have been noted by several investigators, and both physical (temperature, nutrients, depth) and biological (herbivory) influences have been postulated (e.g. Wellington, 1984). Important biogeographic insights from both taxonomic and ecological studies are here presented, and offer a promising platform for further research. Overall, outstanding trends noted by investigators divides the archipelago into 1) Western, 2) Northern, and 3) Southcentral regions based on the diversity and abundance of macroalgal communities. For reference, these regions are depicted in figure 1.

Western Region: Macroalgae of Fernandina Island and the Western coast of Isabela Island are described as "rich, dense, and diverse" (Norris, 1978). Wellington (1975) described this area as having some of the only recognizable macroalgal "communities." In a summary of his field notes, Kendrick (1988a) describes diverse macroalgal communities restricted to lower intertidal and upper subtidal (2-3 m) depths in the Western region, and best developed in exposed locations. He reported species-rich bands of erect, foliose macrophytes (i.e. Asparagopsis, Spathoglossum, Dictyota, Dictyopteris, Sargassum, Corallina, Scinaia, Padina, Gracilaria, Ulva, Hypnea,

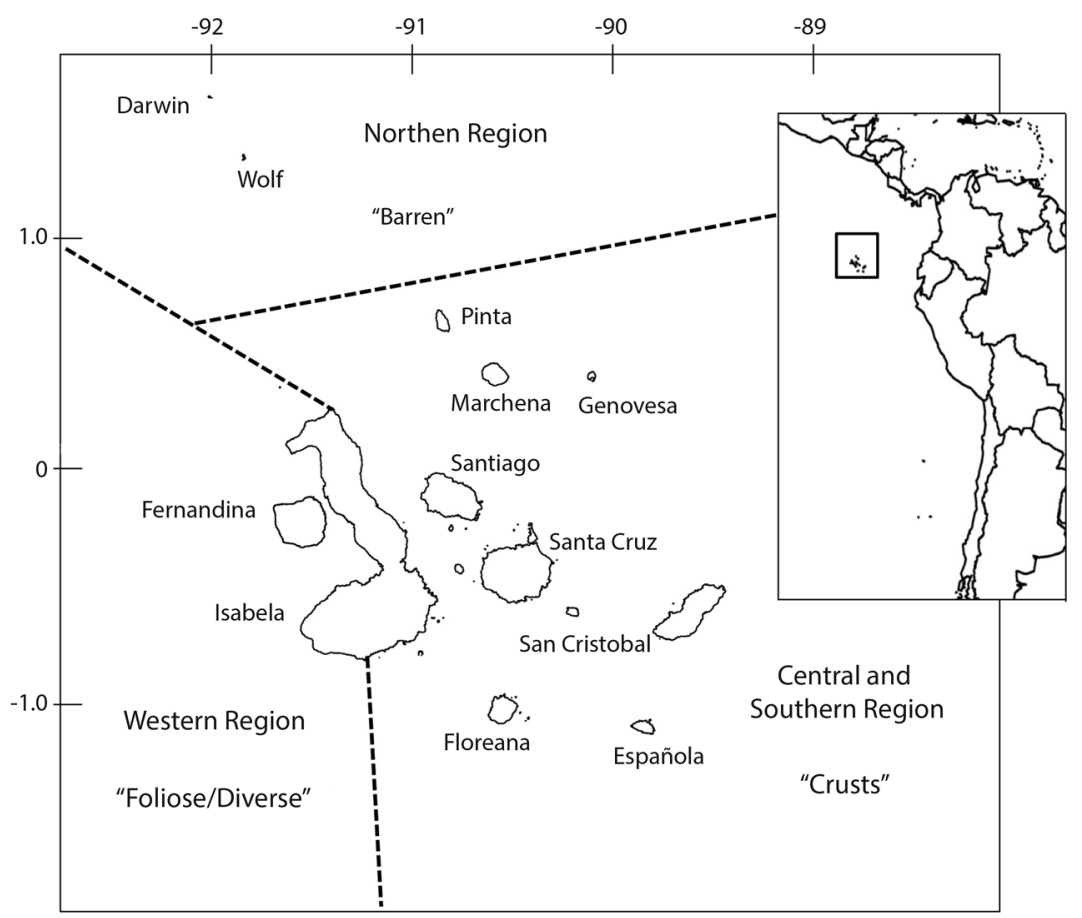

Fig. 1. Theorized regions of Galápagos macroalgae, based on historical observations and collections. Barren $=$ no macroalgal cover; Crusts = prostrate, creeping, or crustose growth forms, patches of foliose or branching species; Foliose/ Diverse $=$ upright, branching or sheetlike growth forms, high species richness. Macroalgal communities have been reported as diverse and abundant in the Western region, virtually non-existent in the Northern region, and generally dominated by crusts with patchy foliose communities in the central/Southern region. Base map courtesy of D. Ruiz. 
Gelidium, Laurencia, Codium, and Kallymenia) in the shallow subtidal of Fernadina and Western Isabela (Kendrick, 1988a).

One of the earliest and most intensive macroalgal-focused studies was that of William Randolph Taylor (1945), based on a 1934 expedition to the islands. Taylor primarily collected intertidally by hand and subtidally with a dredge, though he noted abundant Sargassum (one of the largest and most structurally complex seaweeds in the islands) drifting or washed ashore in the Western region. This observation is corroborated by Garske (2002) who noted large stands of Sargassum of one meter in height in shallow waters of Isabela Island. This area also hosts the only known true "kelp" (brown algae in the order Laminariales) in Galápagos: Eisenia galapagensis (described by Taylor, 1945), a genus normally found in temperate waters. Solitary individuals were collected by dredging near Isla Santa Cruz (central) by Taylor (1945) but the West coast of Isabela (Western region) was recently found to have extensive "forests" of E. galapagensis (Graham, Kinlan, Druehl, Garske, \& Banks, 2007). Prior to this discovery, no kelp forests had been described from tropical latitudes, highlighting the globally unique nature of the Western region.

Northern Region: Macroalgae in the Northern region, specifically around the islands of Darwin and Wolf, has been described as "essentially absent" or "characterized by encrusting corallines and algal turfs" (Wellington, 1975). Not surprisingly, the most conspicuous flora consists mainly of diminutive species of tropical origins, and foliose groups here are represented by Caulerpa and Padina (Garske, 2002). Larger, branching macroalgae have been reported from deep waters in this region, as dredged from 270 meters by Taylor (1945, see below). In general, the Northern region appears to be macroalgally-depauperate, consisting mainly of pavements of crustforming species (Dawson, 1964), at least in shallow water.
Central and Southern Region: Dawson (1964) reported the "general aspect of the seaweed vegetation is one of sparsity. Except for a few species at relatively few localities among Southern islands, the vegetation is not dense or richly developed. Members of the Sargassaceae and Dictyotaceae are the only algae of large size, and these are mainly confined to the South." In this region crusts dominate, and fleshy macroalgae seem to flourish only at very specific localities such as the upwellinginfluenced coasts of Floreana and Española islands, where Taylor (1945) found deeper dredging (to $55 \mathrm{~m}$ ) and intertidal collecting to be particularly productive. He also found dredging in the waters offshore of Puerto Ayora (in Academy Bay, Santa Cruz Island, today the largest settlement in Galápagos) to be "a spectacular success" while the intertidal collecting yielded very little. Garske (2002) describes this same South-Central region as the most interesting in terms of macroalgae; while individuals are typically smaller and sparser than in the West, communities are composed of a mixture of tropical and temperate species, making this region potentially the most biodiverse.

Quantitative estimates of macroalgal standing stocks to parameterize trophic models have varied more than three-fold between the central/Southern region (256.80 tons. $\mathrm{km}^{-2}$ at Floreana Island; Okey et al., 2004) and the Western region (800.48 tons. $\mathrm{km}^{-2}$ at Fernandina Island; Ruiz \& Wolff, 2011). Contrary to historical records and model parameters, an intertidal herbivory study by Vinueza, Menge, Ruiz, and Palacios (2014) recorded higher initial algal abundances (primarily Ulva) at his intertidal site on Santa Cruz (central region), than on Fernandina (Western region). Genovesa (Northern-central) was characterized primarily by crustose coralline algae. These data were collected inside of clustered replicate $30 \times 30$ $\mathrm{cm}$ cages at two nearby sites per island. Due to this design, the discrepancy in algal abundances between those measured and historically observed could be due to small-scale variation (patchiness) in intertidal algal abundances or large-scale regional patterns. 
Depth related distribution patterns: While marine macroalgae are generally most abundant in shallow waters $(<20 \mathrm{~m})$, in clear, tropical waters, living macroalgae have been found to depths of $268 \mathrm{~m}$ (Littler, Littler, Blair, \& Norris, 1985). The deep-water flora of the Canary Islands is known to be particularly abundant and diverse, with new species recently being described and recorded (Haroun, Prud'homme van Reine, Müller, Serrao, \& Herrera, 1993; Sansón, Reyes, Afonso-Carrillo, \& Muñoz, 2002). Brazilian rhodolith beds and diverse epiphytic communities (including the endemic kelp Laminaria abyssalis) span the Equator from $2^{\circ}$ North to $25^{\circ}$ South, and are common in depths greater than $50 \mathrm{~m}$ (AmadoFilho, Maneveldt, Manso, Marins-Rosa, \& Guimarães, 2007).

The steep-sided volcanic islands of Galápagos offer ample hard substrate into deeper water, and light penetrates far below the thermocline (Dawson, 1964; Graham et al., 2007). Throughout the archipelago, depth-related distribution patterns have been described; algae typically flourish at shallower $(0-5 \mathrm{~m})$ and deeper $(>20 \mathrm{~m})$ depths, while intermediate depths are relatively barren (Kendrick, 1988a). Observations from Southern and Western intertidal and very shallow (1-3 m) subtidal communities describe macroalgae as diverse and abundant, yet depauperate only a few meters below. For example, Kendrick (1988a) describes these shallow depths in the Western region as containing "the richest communities and most luxuriant growths of bladed and branched macroscopic algae."

Taylor's (1945) deeper-water dredging $(>30 \mathrm{~m})$ was often very productive; a great deal of his Galápagos collections came from these depths. Of particular interest is his report of collections of Plocamium and Carpomitra from his Northernmost, and deepest, dredging (183-270 $\mathrm{m}$ from Wolf Island). These came from the Northern region where shallower depths $(<20 \mathrm{~m})$ are described as relatively barren (see above). Given the less productive and more transparent surface waters in the North, Dawson (1964) speculated that macroalgae there could be more abundant than in the Southern portion of the archipelago at similar depths (Dawson, 1964). Accordingly, during submersible and SCUBA surveys and collections, Norris (1978) often reported abundant deeper-water algal communities to depths exceeding $110 \mathrm{ft}$ (33 m). Earle (1980) described a "submergence phenomenon" across the islands: large, foliose macroalgal species found throughout shallow waters in the Western region were only present in the rest of archipelago well below the thermocline (> $20 \mathrm{~m}$ depth), where temperatures are colder and more stable.

Also reported from deeper waters is the kelp E. galapagensis mentioned previously (Taylor, 1945; Earle, 1980; Graham et al., 2007). Graham et al. (2007) described "forests" of kelp extending beyond the $60 \mathrm{~m}$ limits of the expedition's survey methods. This is potentially the most ecologically significant macroalgal community in Galápagos, as Eisenia is the physically largest macroalgae so far reported in the archipelago, and presumably one of the most structurally complex biogenic habitats in deeper water.

Role of herbivores: Marine herbivores are known to greatly impact benthic macroalge (Poore et al., 2012). In the competitive relationship between corals and macroalgae, excluding or removing herbivores from the system causes overgrowth of algae and smothering of corals (e.g. Ogden \& Lobel, 1978; Rasher et al., 2012). High abundances of urchins can have an overwhelmingly large influence on the structure of macroalgal communities in both temperate and tropical waters (North \& Pearse, 1970; Carpenter, 1985). High-density urchin "fronts" can consume entire kelp forests, leaving behind barren seascapes that may persist for several years (Leighton, 1971; Dayton, 1985; Chapman \& Johnson, 1990; Andrew, 1993). In the Canary Islands, the influence of urchin grazing was more important than any other measured environmental variable (temperature, wave exposure, sedimentation, among others) in determining patterns of macroalgal biogeography across the archipelago 
(Sangil et al., 2011). Herbivorous fish can also influence the structure of macroalgal communities, and are often cited as major controlling factors of macroalgal growth on coral reefs (Choat, 1991; Ojeda \& Munoz, 1999).

The role of herbivores (primarily urchins) in driving macroalgal distribution patterns in Galápagos has been proposed by several authors (e.g. Dawson, 1964; Norris, 1978; Wellington, 1984) but remains empirically unconfirmed. Macroalgal grazers in the archipelago consist of reptiles (turtles and iguanas), a diverse group of fish species (Appendix), and invertebrates dominated by urchins (Wellington, 1984). Of these, the latter two seem to be in great abundance, possibly enough to have a measureable influence on macroalgal distributions and community composition (Dawson, 1964; Norris, 1978; Kendrick, 1988a).

Common marine herbivores (urchins, fish, iguanas, and crabs) in Galápagos on are known to have an influence on algal physical structure and community composition in intertidal and shallow-subtidal habitats; experimental caged plots excluding these consumers experienced rapid blooms of filamentous and bladed macroalgae while control plots remained relatively barren (Vinueza, Branch, Branch, \& Bustamante, 2006; Irving \& Witman, 2009; Krutwa, 2014). Vinueza et al. (2014) also tested the influence of intertidal grazers (namely urchins, iguanas, and crabs) across productivity gradients in the central and Southern regions of the archipelago. This work found grazing influence on macroalgal community composition and biomass to be most significant at the lowest-productivity site, with less consistent influence at mid-productivity, and little effect at the highest-productivity site. These results could offer insights into the influence of grazers across productivity gradients in subtidal macroalgal assemblages, where herbivorous fish and urchins are much more abundant.

In the Galápagos, the herbivorous fish consist of about 45 species, many of which are obligate herbivores (Appendix). Damselfish are common in shallow waters, and selectively remove undesirable algal species to create polarized patches of algal filaments (Wellington, 1984). They rigorously defend these algal "gardens" from competing urchins and other fish, and maintain algal habitats in shallow waters (Irving \& Witman, 2009). Earle (1980) described the surfaces of rocks at deeper depths $(>20 \mathrm{~m})$ to be covered by a "jungle of red (algae), 15 to $30 \mathrm{~cm}$ high," while noting high grazing activity by herbivorous fish (surgeonfish, parrotfish, girellids, blennies, gobies, and others) in warmer, shallow waters $(<20 \mathrm{~m})$ above the thermocline. McCosker, Taylor and Warner (1978) noted "a paucity of fishes below the nearshore thermocline." Wellington (1984) described large schools of grazing fish (i.e. Prionurus and Scarus) and veneers of closely cropped algal mats. These observations and studies underscore the potentially crucial role of herbivorous fish in structuring subtidal algal assemblages across depth ranges. However, little or no quantitative information exists regarding the generality of this phenomenon.

Urchins, particularly Eucidaris galapagensis, are currently common and abundant throughout the Galápagos, and are reportedly increasing in numbers (Edgar et al., 2010; Glynn \& Wellington, 1983; Ruttenberg, 2001). Glynn and Wellington (1983) speculated that exceedingly high urchin abundances in the Galápagos could be the result of top-predator (shark) removal of urchin predators (pufferfish, wrasses, and triggerfish). Edgar et al. (2010) described geographic ecological trends indicative of a trophic cascade amongst urchins, their predators, and fisheries: decreasing abundances of large predatory fish and lobsters (urchin predators) with proximity to major Galápagos fishing ports, and a concomitant increase in urchin abundances, is thought to be the result of increased fishing pressure over time in the archipelago. Indeed, crustose coralline pavements are noted as common in the Galápagos, and in many places have replaced onceluxuriant and diverse stands of macroalgae (Kendrick, 1988b; Edgar et al., 2010). These observations are consistent with determinations of fleshy macroalgal cover as being negatively correlated with urchin densities, and urchin 
abundances declining with both the presence of predators (lobsters and hogfish), and indices of predation (urchin test remains) (Sonnenholzner, Ladah \& Lafferty, 2009). Abundances of all of the groups surveyed (macroalgae, urchins, and predators) by Sonnenholzner et al. (2009) were significantly related to fishing, with predators and algae declining, and urchin numbers increasing, along gradients of increasing fishing pressure. Because urchins have an overwhelming influence on macroalgal distributions, even in highly-productive upwelling systems (Watanabe \& Harrold, 1991; Hernández, Clemente, Sangil \& Brito, 2008), urchin abundance should be considered as an important factor in any interpretation of macroalgal biogeography in Galápagos.

\section{TEMPORAL DYNAMICS}

Physical and biological influences can dramatically alter macroalgal communities, with cascading effects throughout marine food webs (Mann, 1977; Graham, 2004). These changes can be the result of "regular" seasonal cycles (i.e. ice formation and recession in high latitudes; Barnes, 1999), or anomalous perturbations in coastal ecosystems (i.e. overfishing, pollution). Seasonally-driven species changeovers of the macroalgal components of benthic communities are common, with measureable influences on associated communities (Foster, 1975; Underwood \& Jenakoff, 1984). On coasts in upwelling regions, this shift can happen in a matter of weeks following rapid changes in the parameters of surface waters (Diaz-Pulido \& Garzón-Ferreira, 2002; Vinueza et al., 2006).

In Galápagos, wholesale changes in macroalgal community compositions (from fleshy to filamentous) have been anecdotally noted during ENSO events, to the extent of local and widespread extinctions of conspicuous species (Edgar et al., 2010). Given the abundance of herbivores in the system (see "trophic role" section) this change would undoubtedly cause cascading effects through the marine trophic web. The generality of this phenomenon and its potential for long-term residual effects remain unclear, as there is limited quantitative information regarding macroalgal responses to ENSO events in the Galápagos.

There is, however, an abundance of anecdotal evidence of shifts in macroalgal communities as a result of the ' $82 / 83$ ENSO. Robinson and del Pino (1985) noted a shift in subtidal benthic communities on Floreana to a "monotonous carpet of brown filamentous algae, principally Giffordia and Enteromorpha." In comparing his 1987 observations in Academy Bay (Santa Cruz Island) to those of Wellington in 1975, Kendrick (1988b) described a long term-shift in intertidal community composition. Bladed and branching genera (i.e. Bifucaria, Grateloupia, Prionitis, Gracilaria, Padina, Spatoglossum) had been almost entirely replaced by filamentous and crustose forms (i.e. Cladophora, Chaetomorpha, Giffordia, Ceramium, Polysiphonia, Audouinella). Through an analysis of the background benthos of itchyofaunal images taken during 1982/'83, Edgar et al. (2010) determined that subtidal cover of filamentous and turf algae did increase significantly, while cover of foliose brown algae declined.

Empirical evidence of the 1997/'98 ENSO-related intertidal macroalgal community changes were recorded by Vinueza et al. (2006). Over the course of an intertidal grazerexclusion experiment in Academy Bay (Santa Cruz Island, central region) control plots, initially dominated by Gymogongrus, Ulva, and Enteromorpha, were replaced during the ENSO event by brown and green filaments (Giffordia and Chaetomorpha). Shortly after ocean surface temperatures dropped, Ulva quickly responded and replaced the filaments, and plots were eventually covered by Gymnogongrus (Vinueza et al., 2006). This study highlights the rapid ( $\sim$ one month) ENSO-induced turnover of the intertidal macroalgal community. While in this case the community ultimately recovered, there is evidence of previous long-term changes in intertidal macroalgae following the 1982/'83 ENSO. 
Prior to 1982, the large $(20-30 \mathrm{~cm})$ fucoid alga Bifurcaria galapagensis (Piccone \& Grunow) Womersley 1964 was common and abundant in low intertidal and shallow subtidal waters in the Western and Southern regions, sometimes dominating the intertidal and creating mono-specific stands (Wellington, 1975). This relatively large $\sim 30 \mathrm{~cm}$ alga was recorded in some of the earliest accounts of macroalgae in the archipelago, notably from Isabela Island during the Hassler expedition no. 1019, in June of 1872. Over the next century, it was recorded as conspicuous at most of the other islands, from the intertidal to depths of almost $40 \mathrm{~m}$ (Taylor, 1945; Silva, 1964; Wellington, 1975). Taylor (1945) reported this alga (then as Blossevillea) as the dominant intertidal species on Floreana Island. Silva (1964) reported B. galapagensis from five of the largest islands, and it has been recorded in the majority of pre-1982 macroalgal accounts in the archipelago (Taylor, 1945; Dawson, 1964; Silva, 1964; Wellington, 1975). Bifurcaria galapagensis was very abundant in the intertidal of Academy Bay up until the 1982 ENSO event. It has not been recorded there since (Kendrick, 1988b). In fact, it has since only been recorded at one site on Floreana Island (Garske, 2002; Edgar et al., 2010), and is listed as Critically Endangered by the global IUCN red list (IUCN, 2016). B. galapagensis was not the only macroalgal species to suffer this fate, though due to its large size and intertidal distribution its loss was the most conspicuous. Edgar (2010) also lists six other algal species which, following the ' $82 / 83$ ENSO, are now most likely extinct.

Thermal stress or nutrient limitation could have driven these changes in macroalgal abundances, but the influences of herbivores cannot be overlooked. After considering ENSO phases as factors in their analysis of intertidal grazing influence in Galápagos, Vinueza et al. (2014) found grazer effects on algal biomass generally higher during warm phases, particularly at lowproductivity sites. Additionally, Carr and Bruno (2013) measured higher grazing rates of Galápagos urchins in mesocosms at elevated temperatures. Urchin grazers therefore could be further compounding the effects of high water temperatures and lower nutrients, creating a situation of intensely negative influence on macroalgal growth during ENSO events. This is particularly relevant given the significant increase (by a factor of two) in Eucidaris abundances in the archipelago during and following the ' $82 / 83$ ENSO event (Edgar et al., 2010).

\section{FUNCTIONAL ROLE}

Marine algae are some of the most archaic of the world's primary producers, some being no more complex than plastids and DNA. In shallow temperate waters, macroalgae are a major source of benthic primary productivity and kelp forests, created by brown algae in the order Laminariales, are some of the most productive ecosystems in the world (Mann, 1973). Macroalgae provide direct sustenance to a wide evolutionary range of species. Globally, the macroalgal grazer clade includes marine mammals (sirenians) reptiles (chelonids and squamates), a variety of herbivorous fish (kyphosids, scarids, acanthurids, pomacentrids, siganids, among some others), and a vast array of invertebrates (gastropods, amphipods, decapods, polyplacophorans, echinoderms, among others). Marine subsidies to terrestrial systems in the form of floating macroalgal wrack are a global phenomenon, and offer an important source of organic matter to otherwise nutrient limited (i.e. deserted) island systems (Polis \& Hurd, 1996; Krumhansl \& Scheibling, 2012). Likewise, sinking macroalgal detritus has been estimated to provide the majority of total particulate organic carbon inputs in deepwater canyons (Harrold, Light, \& Lisin, 1998). Decaying macroalgae, the waste produced by herbivores and higher-level consumers in the system, and the decomposing flesh of these consumers is ultimately assimilated by detritivores and microbes. In addition to direct transfer of energy and nutrients, macroalgae offer physical refuges from predation, and can ameliorate light, desiccation, and hydraulic stresses (Dayton, 1975; Fenwick, 1976; Bertness, 
Leonard, Levine, Schmidt, \& Ingraham, 1999; Anderson, 2001; Glasby \& Connell, 2001).

Macroalgal grazers are diverse and abundant in the Galápagos. The grazer guild is represented by reptiles, fish, and invertebrates. The most common marine reptiles in the archipelago are the marine iguana (Amblyrhynchus cristatus) and the green sea turtle (Chelonia mydas), and both feed primarily on macroalgae (Darwin, 1859; Carpenter, 1966; CarriónCortez, Zárate, \& Seminoff, 2010). Carpenter (1966) describes Punta Espinosa on Fernadina Island, where marine iguanas are particularly abundant, as having "the largest lizard biomass anywhere in the world." Marine iguanas may be the most visible and iconic of the macroalgal grazers in the Galápagos, but this phenomenal grazer abundance is likely not unique to this species. A search through the Charles Darwin Foundation's (CDF) species checklists crossreferenced with FishBase dietary information identified 45 potential fish grazers (herbivores and omnivores, Appendix). Some of these species (i.e. Prionurus laticlavius and Scarus ghobban) have been observed throughout the archipelago in large schools (Wellington, 1984). The aforementioned abundances of grazing urchins in the archipelago also points to the potential importance of macroalgae in the system (Norris, 1978; Wellington, 1984; Kendrick, 1988a).

A trophic model created by Ruiz and Wolff (2011) for the Bolivar Channel in the Western region, depicts macroalgae as a keystone functional group, and estimates a standing stock of macroalgal biomass 25 -fold greater than that of phytoplankton in the system. Nine of the 27 higher trophic level (>2.0) functional groups, depend on macroalgal primary productivity, and the total biomass of macroalgal grazers is $43 \%$ of the total consumer biomass. Bottom-up control of this system during ENSO events was modeled by Wolff, Ruiz and Taylor (2012) in the Bolivar Channel (Western region); changes in macroalgal biomasses negatively affected primary consumers, and this effect cascaded through the food web.
A similar model created for Floreana Island in the Southern region resulted in a lower overall importance of macroalge in the system, but a similarly high diversity of grazer functional groups (Okey et al., 2004). This discrepancy could be due to the aforementioned biogeographic differences in macroalgae abundance. While the abundance and diversity of herbivores is one indication of the trophic importance of macroalge in the marine ecosystem of Galápagos, more direct evidence can be found in observed dynamics of these herbivore populations during ENSO events. ENSO related effects on macroalgal herbivore populations, particularly marine iguanas (Amblyrhynchus cristatus), have been highly visible, and wellstudied. Because marine iguanas feed almost exclusively on marine macroalgae (Darwin, 1859; Carpenter 1966; Trillmich \& Trillmich, 1986), their population characteristics are influenced by the availability of macroagal resources, as was evident over the course of the '82/83 ENSO event (Laurie, 1985). Virtually all iguanas measured over this period by Laurie (1985) ceased growth and lost weight, and some populations experienced 50-70\% mortalities. These effects were thought to be the result of changes in intertidal macroalgal assemblages from diverse, energy-rich, digestible stands of foliose genera like Ulva, Centroceras, Gelidium, and Spermothamnium, to mats of low-energy, minimally digestible genera like Giffordia. Necropsies of iguanas during this period revealed intestinal impaction by hard, fibrous algal material (likely algal filaments) to be a common cause of death (Laurie, 1985). Macroalgal community shifts during this ENSO, coupled with increased hydraulic energies and higher sea levels (which further restricted areas available for foraging), undoubtedly contributed to the decline in iguana populations.

\section{DISCUSSION AND FUTURE RESEARCH AVENUES}

Distributions: This review describes a general regional pattern in macroalgal 
distributions based primarily on anecdotes. We here recommend a concentrated effort to investigate affinities of different macroalgal species or communities to the range of environmental conditions and biotic stressors present in the archipelago. In tropical upwelling regions, macroalgal communities can consist of species with both temperate and tropical affinities, an integration which greatly increases species richness, as evidenced by the $\sim 315$ species described in Galápagos (de Guimaraens \& Coutinho, 1996; Garske, 2002). This relationship could explain the anecdotal observations of macroalgal biogeographic patterns in the Galápagos Islands; the consistently cold and nutrient rich waters in the West could be the main reason for the apparent relative high abundance of algae in the region. However, depth and herbivore-related influences could be confounding the effects of temperature, and should be included as potential factors in any sampling design.

Nutrient limitation and high temperatures in surface waters are characteristic of ENSO events in the Eastern Pacific (Houvenaghel, 1984; Glynn, 1988; Wolff, Ruiz, \& Taylor, 2012), however, the clarity of the water in the Galápagos archipelago allows for light penetration well below the thermocline, to depths generally below the influence of ENSO events ( $\sim 20 \mathrm{~m}$, Graham et al., 2007). These deeper waters may act as a refuge from potentially growth-limiting changes in temperatures and nutrient levels, and also may harbor undescribed species of macroalgae. Likewise, shallow (0-5 m depth) macroalgal communities have been reported as locally diverse and abundant (i.e. the Western region), and should be sampled thoroughly.

Severe ENSO events have dramatically altered intertidal macroalgal assemblages in the Galápagos, such as the Bifurcaria phenomenon described previously (Glynn \& Wellington, 1983; Kendrick, 1988b; Vinueza et al., 2006). At such depths, the benthic communities have yet to be extensively surveyed, despite the potential for an abundance of deep-water algal assemblages in the Galápagos (Dawson, 1964).
If present as predicted, these communities could serve important roles in benthic primary productivity and habitat provisioning in the Northern and central regions of the archipelago, where shallow subtidal and intertidal algal assemblages are apparently relatively sparse and species-poor. Here we recommend sampling from the intertidal to a minimum of 30 meters depth (and more if possible) to describe community changes, and quantify depth-related patters across the different geographic regions.

As has been proposed, biotic factors (mainly herbivore influence) could also be influencing distribution patterns. Both urchins and fish grazers are abundant in the Galápagos, and their influence on macroalgal community structure should investigate on much larger scales (across regions), to elucidate the role of herbivory (or abundances of herbivores) in driving biogeographic patterns.

While other studies have focused on biogeography of more visible and charismatic species in Galápagos, a macroalgal-focused investigation would allow for quantification of potential spatial variation in relationships between macroalgal communities and higherorder trophic structure and function across the archipelago. For example, Edgar et al. (2004) defined specific bioregions based on analysis of fish and macroinvertebrate survey data. Incorporation of macroalgal biogeographic patterns could explain some of these results, particularly for variation in abundances of fish and invertebrate herbivores and their predators. This work could further inform spatially-explicit management schemes, and predict changes in trophic function in the case of macroalgal community declines.

Temporal Dynamics: Despite potential ecosystem level ramifications, temporal variability in macroalgal communities has yet to be comprehensively studied in the Galápagos. Our understanding of temporal dynamics of macroalgal populations (and associated trophic repercussions) is mostly based on anecdotal observations, with very few empirical 
studies providing more detailed information. It is known that past ENSO events have caused short-term macroalgal community changeover, long-term elimination of macroalgal species from the archipelago, and devastating effects on iconic, high-profile macroalgal grazers like marine iguanas (Edgar et al., 2010).

Nevertheless, our understanding of the effects of both short and long-term climatic variability in Galápagos on most species of macroalgae (and more importantly macroalgal communities and their consumers) remains speculative at best. Data describing current trends in the spatio-temporal distribution of macroalgal species in the archipelago could corroborate observations of past dynamics. Such work would aid immensely in predicting the influence of future ENSO events on macroalgal distributions, community compositions, and overall ecosystem productivity. Creating a large-scale quantitative baseline for macroalgal biogeography and community compositions in combination with long term monitoring of macroalgal dynamics, is of great importance for clearly identifying locations and timing of community shifts. The necessity for seasonal monitoring was emphasized by Kendrick (1986). Coupled with process-based experiments to investigate the relationships between environmental parameters and intraspecific physiology and interactions, long-term macroalgal monitoring should be made a priority.

Functional Role: As previously mentioned, fish and invertebrate grazers are abundant in Galápagos, which highlights the potential importance of macroalgae in the marine ecosystem. The two regionally-based trophic models described above determined macroalgae to be crucial source of productivity, though they produced large differences in biomasses and resultant level of energy contribution relative to phytoplankton productivity (Okey et al., 2004; Ruiz \& Wolff, 2011). Due to uncertainties regarding geographic variation in macroalgal biomass and productivity, species-specific differences in energy availability, extra-system transport of macroalgae, and un-accounted for herbivore groups, the validity and generality of this phenomenon remains unclear.

Considering the aforementioned anecdotally described macroalgal distributions throughout the Galápagos, and the allegedly "variable" abundance of macroalgae in the Southern region, the model created by Okey et al. (2004; for the Northern coast of Floreana Island in the Southern region) could have been restricted to an area of relatively low macroalgal biomass compared to the Bolivar Channel in the Western region modeled by Ruiz and Wolff (2011). Additionally, unlike the Bolivar channel model, which measured macroalgal biomass within the system, the standing stock estimates for Floreana were based on measurements from a different island (Santa Cruz, $\sim 60 \mathrm{~km}$ to the North), potentially introducing inaccuracy into the biomass parameter. Currently these are the only macroalgal biomass (wet weight standing stock) estimates in existence for Galápagos, but given the uncertainty in their accuracy or generality, it is inappropriate to extrapolate these estimates across the breath of the archipelago. Only a large-scale biogeography and biomass study with effort allocated across the theorized bioregions would provide accurate macroalgal functional group parameters.

Beyond variability in Galápagos macroalgal abundance, more uncertainty in the functional role of macroalgae lies in quantifying its energetic contribution to higher trophic levels. The two models above produced productivity values (Production/Biomass) either arbitrarily (for Floreana) or based on the assumption that Production/Biomass equals total mortality under equilibrium conditions (Bolivar Channel). Regardless, simply quantifying standing biomass of extant macroalgae and using a "mean productivity rate" does not allow for an accurate description of macroalgal trophic function in the system. Macroalgal productivity, caloric values, and palatability (i.e. carbonate or secondary metabolite concentrations) vary by species, and not all species are consumed by all grazer functional groups (Littler \& Arnold, 1982; Paul \& Hay, 1986; Poore et al., 2012). Therefore community species 
composition influences the role the macroalgae play in provisioning energy to the system. As such, investigations of macroalgal productivity in Galápagos should be performed across geographic regions, encompass oceanographic phases (e.g. seasonal through ENSO cycles), and account for species-specific energetic contributions.

Another factor confounding our understanding of the function of macroalge in Galápagos is the potential abundance, diversity, and grazing effect of macroalgal mesograzers. Mesograzers $(<25 \mathrm{~mm})$ can be abundant and diverse in macroalgal habitats, and have been shown to structure macroalgal communities via selective grazing (Brawley, 1992; Taylor, 1998). Previously only macroinvertebrates (> $20 \mathrm{~mm}$ ) were considered when creating trophic webs for Galápagos, ignoring both the biomass and secondary productivity of the potentially important mesograzer functional group.

Macroalgae in Galápagos, large phaeophytes in particular, could be responsible for substantial cross-system subsidies, with floating (i.e. Sargassum) and sinking forms (i.e. Esenia) able to be transported completely out of the system, offering organic enrichment far from their growth area (Krumhansl \& Scheibling, 2012). The complex ocean currents flowing throughout the archipelago readily offer a vector for transport for floating wrack, and sinking detritus can quickly reach a thousand meters on the steep Western and Southern seafloor slopes. In addition to passive transport, the Galápagos experiences a very unique form of cross-system macroalgal transport via the marine iguana. After grazing in the intertidal and shallow subtidal, these reptiles typically defecate while basking on shore, transporting this energy source out of the subtidal realm and creating a potentially important source of organic matter to the otherwise barren volcanic islands (Carpenter, 1966). The potential significance of such cross-system transport of algal productivity, particularly for the younger, more barren islands in Galápagos, warrants further investigation.
The largest phaeophyte genera in Galápagos, specifically Sargassum and Eisenia, can attain lengths of over one meter (Garske, 2002; Graham et al., 2007). Sargassum is densely branched and structurally complex, and elsewhere serves as vital habitat to hundreds of species (Coston-Clements, Settle, Hoss, \& Cross, 1991). These include larvae, recruits, and juveniles, which use the algae as a nursery habitat. Large macroalgal species are likely functioning similarly in Galápagos, and if so, changes in macroalgal community structure like those noted during ENSO events could have indirect ecological effects reaching beyond the food web. Studying the significance of macroalgal habitats in Galápagos, could yield further functional-role insights.

Conclusions and outlook: Given the current paucity of investigations focusing on the macroalgae of Galápagos, there is a plethora of additional research avenues in ecology, evolution, and systematics. Higher-order ecological relationships have received some empirical attention, such as important influences of grazers on macroalgal identity (Irving \& Witman, 2009; Brandt, Witman, \& Chiriboga, 2012; Vinueza et al., 2014). These investigations yielded ecologically interesting results, but with the exception of the work of Vinueza (2014), generality of findings across productivity gradients and stability over time, has yet to be determined. Given the abundance of grazers and higher-order predators in the system, the importance of these ecological relationships in a trophic-web framework should be considered.

Evolutionarily, Galápagos macroalgae offer a range of opportunities for research, including trans-archipelago and continental phylogenetic relationships (estimates of endemism among the taxa range upwards of 40 $\%$, but comprehensive continental taxonomic studies are lacking, particularly in Ecuador and Colombia). The influence of macroalgae on the evolution of certain endemic fauna, particularly the marine iguana, has also yet to be investigated. Molecular evidence suggests that the continental ancestors of the marine iguana 
may have arrived on presently submerged volcanoes as much as 10 million years ago (Rassmann, Tautz, Trillmich, \& Gliddon, 1997). One can imagine that the newly emerged volcanic islands were essentially barren above the surface, with a potentially lush cover of macroalgae in shallow water (much like Fernandina Island today) offering an abundant source of energy and ultimately selectively forcing the evolution of these unique marine reptiles.

Overall, the Galápagos is rife with opportunities for macroalgal investigations. However, given the historically theorized relationship between declining macroalgal productivity and grazer population crashes during ENSO events, priority should be placed on determining baselines of community compositions, biomasses, and productivities throughout the archipelago. Long-term monitoring of these parameters in parallel with the abundance, identity, and health of associated grazers would provide clear evidence of the true trophic role of macroalgae in Galápagos. This could serve as a rapid assessment of the health of the nearshore marine ecosystem, and inform model-based predictions of future ecological change.

\section{ACKNOWLEDGMENTS}

We thank Erica Loor of the Charles Darwin Foundation Library for assistance in locating references, Sonia Cisneros for administrative support, Kathy-Ann Miller for access to the holdings of the Jepson Herbarium, and Carolina Chong for support and technical assistance.

\section{RESUMEN}

\footnotetext{
Macroalgas de Galápagos: una revisión del estado del conocimiento ecológico. Trabajos previos han destacado el papel fundamental de la productividad y dinámica de las macroalgas en el mantenimiento y estructuración de las cadenas alimentarias marinas. La variabilidad espacio temporal de las macroalgas puede alterar ecosistemas costeros, particularmente visibles a lo largo del perfil costero en zonas de proliferación. Como resultado de su ubicación ecuatorial y riqueza en nutrientes, además de eventos de proliferación, el Archipiélago de Galápagos en el Pacífico Oriental acoge un productivo y biodiverso
}

ecosistema marino. Informes y recolección de macroalgas se remontan desde el viaje del Beagle, y desde entonces se han informado más de trescientas especies. No obstante, su función ecológica en el ecosistema no ha sido bien comprendida. Según diversas fuentes de información y en parte anecdóticas, existen abundantes y diversas comunidades de macroalgas en las regiones occidentales del archipiélago, el norte es sustancialmente estéril, y en el centro/sur la abundancia y distribución es variable y menos definida. Tanto las condiciones oceanográficas y la influencia de herbívoros han sido teorizadas para causar este patrón. Grandes cambios en la composición de la productividad y comunidad de macroalgas se han producido durante eventos ENOS fuertes y subsecuentemente han provocado la disminución de poblaciones de iguana marina (herbívoro endémico e icónico) y han sido vinculados a estos cambios. Las iguanas marinas son sólo una de las especies de un grupo diverso y abundante de herbívoros marinos en el sistema, destacando potencialmente el importante rol de la productividad de macroalgas en la cadena alimentaria marina. Esta revisión representa una primera recopilación y análisis de la literatura disponible y presenta temas para futuras investigaciones.

Palabras clave: Galápagos, algas marinas, ENSO, productividad primaria, biogeografía.

\section{REFERENCES}

Adey, W., \& Steneck, R. (2001). Thermogeography over time creates biogeographic regions: a temperature/space/time-integrated model and an abundance weighted test for benthic marine algae. Journal of Phycology, 37, 677-698.

Amado-Filho, G. M., Maneveldt, G., Manso, R. C., Marins-Rosa, B. V., \& Guimarães, S. M. (2007). Estructura de los mantos de rodolitos de 4 a 55 metros de profundidad en la costa sur del estado de Espírito Santo, Brasil. Ciencias Marinas, 33, 399-410.

Anderson, T. (2001). Predator responses, prey refuges, and density-dependent mortality of a marine fish. Ecology, $82,245-257$.

Andrew, N. L. (1993). Spatial heterogeneity, sea urchin grazing, and habitat structure on reefs in temperate Australia. Ecology, 74, 292-302.

Barnes, K. A. (1999). The influence of ice on polar nearshore benthos. Journal of the Marine Biological Association of the United Kingdom, 79, 401-407.

Bell, P. R. F. (1992). Eutrophication and coral reefs-some examples in the Great Barrier Reef lagoon. Water Research, 26, 553-568.

Bertness, M. D., Leonard, G., Levine, J. M., Schmidt, P., \& Ingraham, A. O. (1999). Habitat modification by algal canopies: Testing the relative contribution of 
positive and negative interactions in rocky intertidal communities. Ecology, 80, 2711-2726.

Bodkin, J. (1988). Effects of kelp forest removal on associated fish assemblages in central California. Journal of Experimental Marine Biology and Ecology, $117,227-238$.

Brandt, M., Witman, J. D., \& Chiriboga, A. I. (2012). Influence of a dominant consumer species reverses at increased diversity. Ecology, 93, 868-878.

Brawley, S. H. (1992). Mesoherbivores. In D. M. John, S. J. Hawkings, \& J. H. Price (Eds.). Plant-Animal Interactions in the Marine Benthos (pp. 253-263). Oxford, UK: Clarendon Press.

Bustamante, R., \& Branch, G. (1996). Large scale patterns and trophic structure of southern African rocky shores: the roles of geographic variation and wave exposure. Journal of Biogeography, 23, 339-351.

Carpenter, C. (1966). The marine iguana of the Galápagos Islands, it's behavior and ecology. Proceedings of the California Academy of Sciences, Fourth Series, 34, 329-376.

Carpenter, R. C. (1985). Sea urchin mass-mortality: Effects on reef algal abundance, species composition, and metabolism and other coral reef herbivores. Proceedings of the Fifth International Coral Reef Symposium, 4, 53-60.

Carr, L., \& Bruno, J. (2013). Warming increases the topdown effects on metabolism of a subtidal herbivore. PeerJ Computer Science, 1, e109.

Carrión-Cortez, J. A., Zárate, P., \& Seminoff, J. A. (2010). Feeding ecology of the green sea turtle (Chelonia mydas) in the Galápagos Islands. Journal of the Marine Biological Association of the United Kingdom, 90, 1005-1013.

Chapman, A. R., \& Johnson, C. R. (1990). Disturbance and organization of macroalgal assemblages in the Northwest Atlantic. Hydrobiologia, 192, 77-121.

Choat, J. (1991). The biology of herbivorous fishes on coral reefs. In P. Sale (Ed.), The Ecology of Fishes on Coral Reefs (pp. 120-155). San Diego, Ca.: Academic Press, Inc.

Coston-Clements, L., Settle, L. R., Hoss, D. E., \& Cross, F. A. (1991). Utilization of the Sargassum habitat by marine invertebrates and vertebrates: a review. NOAA Technical Memorandum NMFS-SEFSC, 296, 32.

Darwin, C. (1859). On the Origin of Species by Means of Natural Selection, or the Preservation of Favoured Races in the Struggle for Life. London, England: John Murray.

Dawson, E. Y. (1964). Marine Algae of the Galápagos. Noticias de Galápagos, 4, 11-12.
Dayton, P. K. (1985). Ecology of kelp communities. Annual Review of Ecology, Evolution, and Systematics, 16, 215-245.

Dayton, P. K. (1975). Experimental evaluation of ecological dominance in a rocky intertidal algal community. Ecological Monographs, 45, 137-159.

de Guimaraens, M. A., \& Coutinho, R. (1996). Spatial and temporal variation of benthic marine algae at the Cabo Frio upwelling region, Rio de Janeiro, Brazil. Aquatic Botany, 52, 283-299.

Diaz-Pulido, G., \& Garzón-Ferreira, J. (2002). Seasonality in algal assemblages on upwelling-influenced coral reefs in the Colombian Caribbean. Botanica Marina, $45,284-292$.

Earle, S. (1980). Marine plant and animal distributions in relation to the Galápagos nearshore thermocline. Noticias de Galápagos, 32, 16-18.

Edgar, G. J., Banks, S., Farina, J. M., Calvopina, M., \& Martinez, C. (2004). Regional biogeography of shallow reef fish and macro-invertebrate communities in the Galápagos archipelago. Journal of Biogeography, $31,1107-1124$

Edgar, G. J., Banks, S. A., Brandt, M., Bustamante, R. H., Chiriboga, A., Earle, S. A., ... Wellington, G. M. (2010). El Niño, grazers and fisheries interact to greatly elevate extinction risk for Galápagos marine species. Global Change Biology, 16, 2876-2890.

Fenwick, G. D. (1976). The effect of wave exposure on the amphipod fauna of the alga Caulerpa brownii. Journal of Experimental Marine Biology and Ecology, 25, 1-18.

Foster, M. S. (1975). Algal succession in a Macrocystis pyrifera forest. Marine Biology, 32, 313-329.

Garske, L. (2002). Macroalgas Marinas. In E. Danulat \& G. J. Edgar. Reserva Marina de Galápagos: Linea Base de la Biodiversidad (pp. 419-439). Puerto Ayora, Santa Cruz, Galápagos: Fundacion Charles Darwin/ Servicio Parque Nacional Galápagos.

Glasby, T., \& Connell, S. (2001). Orientation and position of substrata have large effects on epibiotic assemblages. Marine Ecology Progress Series, 214, 127-135.

Glynn, P. W. (1988). El Nino-Southern Oscillation 19821983: Nearshore population, community, and ecosystem responses. Annual Review of Ecology, Evolution, and Systematics, 19, 309-345.

Glynn, P. W., \& Wellington, G. M. (1983). Corals and Coral Reefs of the Galápagos Islands. Berkeley, Ca.: University of California Press.

Graham, M. H. (2004). Effects of local deforestation on the diversity and structure of southern California giant kelp forest food webs. Ecosystems, 7, 341-357. 
Graham, M., Kinlan, B., Druehl, L., Garske, L., \& Banks, S. (2007). Deep-water kelp refugia as potential hotspots of tropical marine diversity and productivity. Proceedings of the National Academy of Sciences, 104, 16576-16580.

Grehan, J. (2001). Biogeography and evolution of the Galápagos: integration of the biological and geological evidence. Biological Journal of the Linnean Society, 74, 267-287.

Haroun, R. J., Prud'homme van Reine, W. F., Muller, D. G., Serrao, E., \& Herrera, R. (1993). Deep-water macroalgae from the Canary Islands: new records and biogeographical relationships. Helogolander Meersuntersuchungen, 47, 125-143.

Harris, M. (1969). Breeding seasons of sea-birds in the Galápagos Islands. Journal of Zoology, 159, 145-165.

Harrold, C., Light, K., \& Lisin, S. (1998). Organic enrichment of submarine-canyon and continental-shelf benthic communities by macroalgal drift imported from nearshore kelp forests. Limnology and Oceanography, 43, 669-678.

Hernández, J., Clemente, C., Sangil, C., \& Brito, A (2008). The key role of the sea urchin Diadema aff. antillarum in controlling macroalgae assemblages throughout the Canary Islands (eastern subtropical Atlantic): an spatio-temporal approach. Marine Environmental Research, 66, 259-270.

Houvenaghel, G. T. (1984). Oceanographic setting of the Galápagos Islands. In R. Perry (Ed.), Key Environments, Galápagos (pp. 43-54). New York: Pergamon Press

Irving, A., \& Witman, J. (2009). Positive effects of damselfish override negative effects of urchins to prevent an algal habitat switch. Journal of Ecology, 97, 337-347.

IUCN. (2016). The IUCN Red List of Threatened Species. Version 2016-1. Retrieved from http://www.iucnredlist.org

Kendrick, G. A. (1986). The benthic marine algal flora. Perto Ayora, Santa Cruz, Galápagos: Chales Darwin Foundation.

Kendrick, G. A. (1988a). Preliminary survey of the marine benthos of the western parts of Isla Isabela and Isla Fernandina (Unpublished trip report). Galápagos, Ecuador: Charles Darwin Research Station.

Kendrick, G. A. (1988b). Where have all the algae gone? Noticias de Galápagos, 46, 16-17.

Kerswell, A. P. (2006). Global biodiversity patterns of benthic marine algae. Ecology, 87, 2479-2488.

Krumhansl, K. A., \& Scheibling, R. E. (2012). Production and fate of kelp detritus. Marine Ecology Progress Series, 467, 281-302.
Krutwa, A. (2014). Small-scale differences in tropical subtidal rocky reef communities of Floreana Island, Galápagos (Ph.D. Dissertation). University of Bremen, Germany.

Laurie, A. (1985). The effect of the 1982-1983 El Nino on marine iguanas. In G. Robinson, \& E. del Pino, El Niño in the Galápagos Islands: The 1982-1983 event (pp. 199-209). Quito, Ecuador: Charles Darwin Foundation.

Leighton, D. L. (1971). Grazing activities of benthic invertebrartes in southern California kelp beds. Nova Hedwigia Beihefte, 32, 421-453.

Lilley, S., \& Schiel, D. (2006). Community effects following the deletion of a habitat-forming alga from rocky marine shores. Oecologia, 148, 672-681.

Littler, M. M., \& Arnold, K. E. (1982). Primary productivity of marine macroalgal functional-form groups from southwestern North America. Journal of Phycology, 18, 307-311.

Littler, M. M., Littler, D. S., Blair, S. M., \& Norris, J. N. (1985). Deepest known plant life discovered on an uncharted seamount. Science, 227, 57-59.

Lobban, C. S., \& Harrison, P. J. (1997). Seaweed Ecology and Physiology. Cambridge: Cambridge University Press.

Mann, K. H. (1973). Seaweeds: their productivity and strategy for growth. Science, 182, 975-981.

Mann, K. H. (1977). Destruction of kelp-beds by seaurchins: a cyclical phenomenon or irreversible degradation? Helgoländer Wissenschafteliche Meersuntersuchungen, 30, 455-467.

McCosker, J. J., Taylor, L., \& Warner, R. R. (1978). Ichthyological studies at Galápagos. Noticias de Galápagos, 27, 13-15.

Norris, J. (1978). Smithsonian Institution's Galápagos marine algal program. Noticias de Galápagos, $27,24-25$.

North, W. J., \& Pearse, J. S. (1970). Sea urchin population explosion in southern California coastal waters. Science, 167, 209.

Ojeda, F. P., \& Munoz, A. A. (1999). Feeding selectivity of the herbivorous fish Scartichthys viridis: effects on macroalgal community structure in a temperate rocky intertidal coastal zone. Marine Ecology Progress Series, 184, 219-229.

Okey, T. A., Banks, S., Born, A. F., Bustamante, R. H., Calvopiña, M., Edgar, G. J., Espinoza, E., Farina, J. M., Garske, L., Reck, G., Salazar, S., Shepard, S., ToralGranda, V., \& Wallem, P. (2004). A trophic model of a Galápagos subtidal rocky reef for evaluating fisheries 
and conservation strategies. Ecological Modelling, $172,383-401$.

Ogden, J., \& Lobel, P. (1978). The role of herbivorous fishes and urchins in coral reef communities. Environmental Biology of Fish, 3, 49-63.

Palacios, D. M. (2003). Oceanographic conditions around the Galápagos Archipelago and their influence on cetacean community structure. Corvallis, Oregon: Oregon State University.

Palacios, D. M. (2004). Seasonal patterns of sea-surface temperature and ocean color around the Galápagos: regional and local influences. Deep Sea Research Part II: Topical Studies in Oceanography, 51, 43-57.

Paul, V. J., \& Hay, M. E. (1986). Seaweed susceptibility to herbivory: chemical and morphological correlates. Marine Ecology Progress Series, 33, 255-264.

Pennington, J. T., Mahoney, K. L., Kuwahara, V. S., Kolber, D. D., Calienes, R., \& Chavez, F. P. (2006). Primary production in the eastern tropical Pacific: A review. Progress in Oceanography, 69, 285-317.

Polis, G. A., \& Hurd, S. D. (1996). Linking marine and terrestrial food webs: Allochthonous input from the ocean supports high secondary productivity on small islands and coastal land communities. The American Naturalist, 147, 396-423.

Poore, A. G. B., Campbell, A. H., Coleman, R. A., Edgar, E. G., Jormalainen, V., Reynolds, P. L., Sotka, E. E., Stachowicz, J. J., Taylor, R. B., Vanderklift, M. A., \& Duffy, J. E. (2012). Global patterns in the impact of marine herbivores on benthic primary producers. Ecology Letters, 15, 912-922.

Rasher, D. B., Engel, S., Bonito, V., Fraser, G. J., Monotoya, J. P., \& Hay, M. E. (2012). Effects of herbivory, nutrients, and reef protection on algal proliferation and coral growth on a tropical reef. Oecologia, 169, 187-198.

Rassmann, K., Tautz, D., Trillmich, F., \& Gliddon, C. (1997). The microevolution of the Galápagos marine iguana Amblyrhynchus cristatus assessed by nuclear and mitochondrial genetic analyses. Molecular Ecology, 6, 437-452.

Robinson, G., \& del Pino, E. (1985). El Niño in the Galápagos Islands: The 1982-1983 event. Quito, Ecuador: Charles Darwin Foundation.

Ruiz, D., \& Wolff, M. (2011). The Bolivar Channel ecosystem of the Galápagos Marine Reserve: Energy flow structure and role of keystone groups. Journal of Sea Research, 66, 123-134.
Ruttenberg, B. (2001). Effects of artisanal fishing on marine communities in the Galápagos Islands. Conservation Biology, 15, 1691-1699.

Sangil, C., Sansón, M., \& Afonso-Carrillo, J. (2011). Spatial variation patterns of subtidal seaweed assemblages along a subtropical oceanic archipelago: Thermal gradient vs. herbivore pressure. Estuarine, Coastal and Shelf Science, 94, 322-333.

Sansón, M., Reyes, J., Afonso-Carrillo, J., \& Muñoz, E. (2002). Sublittoral and deep-water red and brown algae new from the Canary Islands. Botanica Marina, $45,35-49$.

Santelices, B., Bolton, J. J., \& Meneses, I. (2009). Marine Algal Communities. In J. D. Witman, \& K. Roy (Eds.), Marine Macroecology (pp. 153-192). Chicago, USA: University of Chicago Press.

Schils, T., \& Coppejans, E. (2003a). Phytogeography of upwelling areas in the Arabian Sea. Journal of Biogeography, 281, 1339-1356.

Schils, T., \& Coppejans, E. (2003b). Spatial variation in subtidal plant communities around the Socotra Archipelago and their biogeographic affinities within the Indian Ocean. Marine Ecology Progress Series, 251, 103-114.

Silva, P. (1964). Status of our knowledge of the Galápagos benthic marine algal flora. Papers of the Galápagos International Science Project. The Galápagos Islands Symposium (pp. 67-84). California, USA: University of California Press.

Sonnenholzner, J. I., Ladah, L. B., \& Lafferty, K. D. (2009). Cascading effects of fishing on Galápagos rocky reef communities: Reanalysis using corrected data. Marine Ecology Progress Series, 375, 209-218.

Taylor, W. R. (1945). Pacific Marine Algae of the Allan Hancock Expeditions to the Galápagos Islands. Los Angeles, Ca.: The University of Southern California Press.

Taylor, R. (1998). Density, biomass, and productivity of animals in four subtidal rocky reef habitats: the importance of small mobile invertebrates. Marine Ecology Progress Series, 172, 37-51.

Trillmich, K. G., \& Trillmich, F. (1986). Foraging strategies of the marine iguana, Amblyrhynchus cristatus. Behavioral Ecology and Sociobiology, 18, 259-266.

Underwood , A. J., \& Jerknakoff, P. (1984). The effects of tidal height, wave-exposure, seasonality, and rockpools on grazing and the distribution of intertidal macroalgae in New South Wales. Journal of Experimental Marine Biology and Ecology, 75, 71-96. 
Vinueza, L. R., Branch, G. M., Branch, M. L., \& Bustamante, R. H. (2006). Top-down herbivory and bottom-up El Nino effects on Galápagos rocky-shore communities. Ecological Monographs, 76, 111-131.

Vinueza, L. R., Menge, B. A., Ruiz, D., \& Palacios, D. M. (2014). Oceanographic and climatic variation drive top-down/bottom-up coupling in the Galápagos intertidal meta-ecosystem. Ecological Monographs, 84, 411-434.

Watanabe, J. M., \& Harrold, C. (1991). Destructive grazing by sea urchins Strongylocentrotus spp. in a central California kelp forest: potential roles of recruitment, depth, and predation. Marine Ecology Progress Series, 71, 125-141.
Wellington, G. M. (1984). Marine environment and protection. In R. Perry (Ed.), Key Environments: Galápagos (pp. 247-263). Oxford: Pergamon Press.

Wellington, G. M. (1975). The Galápagos coastal marine environments. A resource report to the Department of National Parks and Wildlife. Quito, Ecuador: Department of National Parks and Wildlife.

Wolff, M., Ruiz, D., \& Taylor, M. (2012). El Nino induced changes to the Bolivar Channel ecosystem (Galápagos): comparing model simulations with historical biomass time-series. Marine Ecology Progress Series, 448, 7-22. 


\section{APPENDIX}

List of fish potentially grazing on macroalgae in Galápagos, generated by cross-referencing the Charles Darwin Foundation Datazone's fish checklist (http://www.darwinfoundation.org/datazone/checklists/vertebrates/pisces/) with dietary information found in fishbase (http://fishbase.sinica.edu.tw/search.php)

\begin{tabular}{|c|c|c|c|c|}
\hline Genus & species & Common name (English) & Family & $\operatorname{Diet}^{1}$ \\
\hline Prionurus & laticlavius & Razor surgeonfish & Acanthuridae & $\mathrm{h}$ \\
\hline Acanthurus & nigricans & Velvet surgeonfish & Acanthuridae & $\mathrm{h}$ \\
\hline Acanthurus & triostegus & Convict surgeon & Acanthuridae & $\mathrm{h}$ \\
\hline Acanthurus & xanthopterus & Ringtailed surgeonfish & Acanthuridae & $\mathrm{h} / \mathrm{o}$ \\
\hline Naso & brevirostris & Spotted unicornfish & Acanthuridae & $\mathrm{h}$ \\
\hline Naso & vlamingii & Bignose unicornfish & Acanthuridae & o \\
\hline Microspathodon & dorsalis & Giant damselfish & Pomacentridae & $\mathrm{h}$ \\
\hline Microspathodon & bairdii & Bumphead damselfish & Pomacentridae & $\mathrm{h}$ \\
\hline Stegastes & beebei & Southern whitetail major & Pomacentridae & $\mathrm{h}$ \\
\hline Stegastes & arcifons & Island major & Pomacentridae & $\mathrm{h}$ \\
\hline Stegastes & acapulcoensis & Acapulco major & Pomacentridae & $\mathrm{h}$ \\
\hline Abudefduf & troschelii & Seargent major & Pomacentridae & $\mathrm{h} / \mathrm{p}$ \\
\hline Nexilosus & latifrons & Coquito sergeant & Pomacentridae & $\mathrm{h}$ \\
\hline Abudefduf & concolor & Dusky seargent & Pomacentridae & $\mathrm{h} / \mathrm{p}$ \\
\hline Holocanthus & passer & King angelfish & Pomacanthidae & $\mathrm{h} / \mathrm{o}$ \\
\hline Girella & freminvilli & Dusky chub & Kyphosidae & $\mathrm{h}$ \\
\hline Kyphosus & analogus & Blue-bronze sea chub & Kyphosidae & $\mathrm{h}$ \\
\hline Kyphosus & elegans & Cortez sea chub & Kyphosidae & $\mathrm{h}$ \\
\hline Chaetodon & auriga & Threadfin butterflyfish & Chaetodontidae & o \\
\hline Chaetodon & humeralis & Threebanded butterflyfish & Chaetodontidae & o \\
\hline Chaetodon & kleinii & Sunburst butterflyfish & Chaetodontidae & o \\
\hline Chaetodon & lunula & Raccoon butterflyfish & Chaetodontidae & o \\
\hline Johnrandallia & nigrirostris & Blacknosed butterflyfish & Chaetodontidae & o \\
\hline Prognathodes & carlhubbsi & Southern scythe-marked butterflyfish & Chaetodontidae & o \\
\hline Eucinostomus & argenteus & Silver mojarra & Chaetodontidae & o \\
\hline Eucinostomus & currani & Pacific flagfin mojarra & Chaetodontidae & o \\
\hline Eucinostomus & dowii & Dow's mojarra & Gerreidae & o \\
\hline Bodianus & eclancheri & Galápagos hogfish & Labridae & o \\
\hline Calotomus & carolinus & Carolines parrotfish & Scaridae & $\mathrm{h}$ \\
\hline Nicholsina & denticulata & Loosetooth parrotfish & Scaridae & $\mathrm{h}$ \\
\hline Scarus & compressus & Azure parrotfish & Scaridae & $\mathrm{h}$ \\
\hline Scarus & ghobban & Blue-barred parrotfish & Scaridae & $\mathrm{h}$ \\
\hline Scarus & perrico & Bumphead parrotfish & Scaridae & $\mathrm{h}$ \\
\hline Scarus & rubroviolaceus & Ember parrotfish & Scaridae & $\mathrm{h}$ \\
\hline Ophioblennius & steindachneri & Large-banded blenny & Blenniidae & $\mathrm{h} / \mathrm{o}$ \\
\hline Oplegnathus & insignis & Pacific beakfish & Oplegnathidae & $\mathrm{h} / \mathrm{o}$ \\
\hline Athron & hispidus & White-spotted puffer & Tetraodontidae & o \\
\hline Canthigaster & amboinensis & Sharpnose pufferfish & Tetraodontidae & $\mathrm{h} / \mathrm{o}$ \\
\hline Melichthys & niger & Black triggerfish & Balistidae & $\mathrm{h} / \mathrm{o}$ \\
\hline Melichthys & vidua & Pink triggerfish & Balistidae & $\mathrm{h} / \mathrm{o}$ \\
\hline Aluterus & scriptus & Scribbled leatherjacket filefish & Monacanthidae & o \\
\hline Cantherhines & dumerilii & Whitespotted filefish & Monacanthidae & o \\
\hline Ostracion & meleagris & Whitespotted boxfish & Ostraciidae & o \\
\hline Chanos & chanos & Milkfish & Chanidae & $\mathrm{o}$ \\
\hline
\end{tabular}

${ }^{1} \mathrm{~h}=$ herbivore, $\mathrm{o}=$ omnivore, $\mathrm{p}=$ planktivore. 